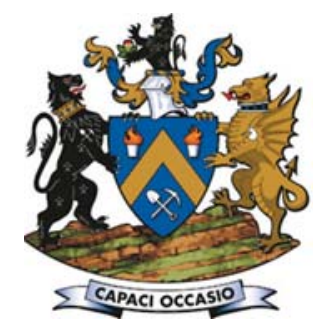

\title{
Qualitative hydrogeological assessment of vertical connectivity in aquifers surrounding an underground coal gasification site
}

\author{
by L.S. Mokhahlane*, G. Mathoho ${ }^{\dagger}$, M. Gomo*, and \\ D. Vermeulen*
}

\section{Synopsis}

Underground coal gasification (UCG) is the conversion of coal in situ into a usable synthetic gas. One of the major environmental concerns with UCG is the possibility of groundwater from the coal seam aquifer contaminating the shallow aquifers via hydraulic connections. The coal seam aquifers are usually confined aquifers but can have hydraulic connections to the shallow aquifers due to faults/fractures or any man-made connections, including boreholes. The aim of this paper is to study groundwater hydraulic connections across various aquifers at the UCG site at Majuba, using hydrochemistry and stable isotope $\left(\delta^{18} \mathrm{O}\right.$ and $\left.\delta^{2} \mathrm{H}\right)$ tools. Physical and chemical processes such as diffusion and condensation generate isotopic differentiation in natural waters that can be used to deduce the origins of different waters, and in groundwater the spatial isotopic distribution can be used to deduce hydraulic connections between different aquifers. The Majuba UCG site consists of shallow, intermediate, and saline deep aquifer systems at a depth of $70 \mathrm{~m}, 180 \mathrm{~m}$, and $300 \mathrm{~m}$ respectively. Samples were taken from each aquifer system together with supplementary samples from an on-site water storage dam. The analyses of isotopic compositions led to the determination of the possible sources of each sample. The deep aquifer is represented by an isotopic signature that is depleted in heavy isotopes with average values of $-41.7 \%$ and $-7.02 \%$ for $\delta^{18} \mathrm{O}$ and $\delta^{2} \mathrm{H}$ respectively, while the shallow aquifer is enriched with corresponding average values of $-19.9 \%$ and $-3.3 \%$. Hydrochemical data also showed different water types: a sodium chloride type in the deep aquifer and a sodium bicarbonate water in the shallow aquifer. The results indicate that the shallow aquifer and the deep aquifer are not hydraulically connected, and therefore it is unlikely that groundwater from the gasification zone would contaminate the shallow aquifer.

\section{Keywords}

underground coal gasification, hydraulic connectivity, stable isotopes, hydrochemistry, Majuba, aquifer.

\section{Introduction}

Underground coal gasification (UCG) is a mining method that exploits coal seams by in situ gasification that yields a usable synthetic gas. This process uses a panel of injection and production wells to achieve gasification and transport the synthetic gas to the surface without the need for people to go underground. Compared to conventional coal mining the appeal of UCG is multidimensional. The advantages include improved health and safety, reduction in process and waste handling, and less surface damage from mining activity (Imran et al., 2014). The UCG process nonetheless raises some environmental concerns, some of which relate to the potential contamination of aquifers around the gasification zone (Kapusta and Stańczyk, 2015). This is due to the decomposition of coal in the gasification zone, which produces organic pollutants such as benzene, polycyclic aromatic hydrocarbons (PAHs), phenols, and inorganic compounds including ammonia and sulphides (Bhutto, Bazmi, and Zahedi, 2013; Kapusta and Stańczyk, 2011). These contaminants can migrate and penetrate the surrounding aquifers as a result of an outward pressure from the gasification zone if the gasifier is operated at a pressure higher than the hydrostatic pressure in the coal seam aquifer (Burton, Friedmann, and Upadhye, 2006). Once gasification is complete, the natural groundwater will begin to fill the cavity and cool the gasification zone. The flow of groundwater in the cavity will ultimately lead to leaching of residue products such as ash, unburned coal, and chars, which can lead to groundwater contamination (Liu et al., 2007). The solubility of metals increases with increasing temperature and this can lead to long-term leaching of metals from the cavity.

Heat penetration can alter the overlying rocks and create fractures that result in the coal seam aquifer becoming hydraulically connected to the shallow aquifer, which can lead to the draining of the shallow aquifer into the gasification zone (Figure 1). The confined nature of the coal (deep) seam aquifer allows its water level (head) to stabilize at shallower levels above the coal seam depth (Dvornikova, 2018). The hydraulic connections can ultimately transmit water contaminated with inorganic and organic UCG products from the gasification zone to the shallow levels, where subsequent contamination of pristine shallow

* Institute for Groundwater Studies, University of the Free State, South Africa.

+ School of Chemical and Metallurgical Engineering, University of the Witwatersrand, South Africa.

(C) The Southern African Institute of Mining and Metallurgy, 2018. ISSN 2225-6253. Paper received Apr. 2018; revised paper received Aug. 2018. 


\section{Qualitative hydrogeological assessment of vertical connectivity in aquifers surrounding}

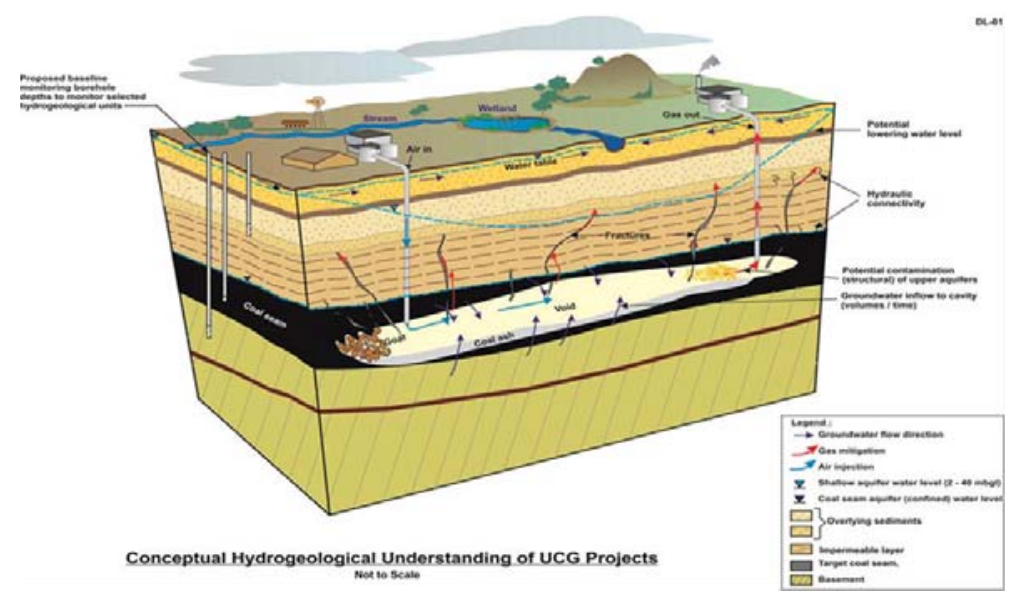

Figure 1-Conceptual hydrogeological model of a UCG plant (adapted from Love et al., 2014)

aquifers can occur. UCG operators have to ensure that the site is well characterized and that the coal seam has limited connectivity with other water sources (Imran et al., 2014)

Subsidence of the overburden above the UCG burn void can also result in serious groundwater contamination where aquifer cross-connection ensued during gasification operations, which can result in the transmission of pollutants generated in the burn zone via fractures triggered by subsiding overburden into overlying aquifers (Liu et al., 2007). Overburden failure can create joints and fractures (Ghasemi et al., 2012), similar to those seen in Figure 1, and these can act as pathways for contaminants to migrate from the UCG cavity to the shallower aquifers. The environmental risks of groundwater pollution from UCG activities are mostly site-specific. Appropriate site selection can mitigate most of the potential risks of groundwater contamination as factors such as depth of cover and competency of overlying rock play a role in roof collapse (Ghasemi et al., 2012; Imran et al., 2014). If there is no hydraulic connection between the shallow aquifers and the coal seam aquifer, where gasification is undertaken, there is little risk of groundwater contamination. Usually the water in the coal seam aquifer is of poor quality and is not used for any domestic or agricultural purposes. However, if faults and fractures exist within the strata, a hydraulic connection can be created between the coal seam aquifer and the shallow aquifer as seen in Figure 1.

Water is made up of oxygen and hydrogen atoms that exist as various stable isotopes. In natural waters the isotopic ratios of oxygen and hydrogen vary due to chemical, biological, and physical processes. For example in cooler regions the equilibrium water vapour would have an isotopic composition of $\delta^{18} \mathrm{O}=-10.6 \%$ and $\delta^{2} \mathrm{H}=-93 \%$, while over high-latitude seas the isotopic signature is as low as $\delta^{18} \mathrm{O}=-$ $11.6 \%$ and $\delta^{2} \mathrm{H}=-10 \%$ (Clark and Fritz, 1997). These variations are a result of isotopic fractionation during phase transitions such as condensation and evaporation, and are also dependent on temperature changes. For example, during evaporation, the water in the vapour phase becomes is enriched in the lighter isotopic fractions $\delta^{16} \mathrm{O}$ and $\delta^{1} \mathrm{H}$, leaving behind water that is enriched in $\delta^{18} \mathrm{O}$ and $\delta^{2} \mathrm{H}$. The isotopic ratios can be used as a quantitative tool to identify the admixture between various surface water bodies and subsurface waters. This provides a means to determine the conditions during groundwater recharge by determining the $\delta^{18} \mathrm{O}$ and $\delta^{2} \mathrm{H}$ compositions in borehole samples (Clark and Fritz, 1997).

The aim of this paper is to study groundwater hydraulic connections across various aquifers at the UCG site at Majuba, using hydrochemistry and stable isotopes $\left(\delta^{18} 0\right.$ and $\left.\delta^{2} \mathrm{H}\right)$, in order to assess the environmental risk to groundwater post the first gasification phase. A 3D geological model of the site will be developed and used to analyse the environmental risk.

\section{Geological and hydrogeological setting}

The Majuba UCG pilot plant is located in Mpumalanga Province of South Africa, about $35 \mathrm{~km}$ northwest of the town of Volkrust. Regular hills attributed to the erosion of the underlying dolerite sill typify the topography. The site covers an area of around 60 ha on the eastern bank of the Witbankspruit River and the surrounding area is mostly used for agricultural activities (Figure 2).

Four different dolerite intrusions (T1 to T4) that intersect the Karoo sediments at the Majuba Colliery have been identified (de Oliveira and Cawthorn, 1999). The intrusions have displaced the targeted Gus seam by over $70 \mathrm{~m}$ in some places. This has led to limitations in effective extraction of the coal seam by conventional mining. A 3D geological model of the Majuba UCG site is displayed in Figure 3. The model was developed from drill-hole core logs and generated using Leapfrog version 4.2. The geological model shows that the lateral extend of the two dolerite dykes is generally even across the study area. The dolerite intrusions have broken up the coal reserves into minor blocks, which is beneficial in containing the UCG process underground (Pershad, Pistorius, and van der Riet, 2018). The targeted coal seam (the Gus seam ) is located at an average depth of over $250 \mathrm{~m}$, and the second dolerite (T2) is over $100 \mathrm{~m}$ thick, which assists with the isolation of the gasification zone from the shallow aquifer.

The Gus seam forms part of the Vryheid Formation of the Ecca Group in the Karoo Supergroup (Snyman, 1998). The Gus seam varies from 1.8 to $4.5 \mathrm{~m}$ in thickness and at the 


\section{Qualitative hydrogeological assessment of vertical connectivity in aquifers surrounding}

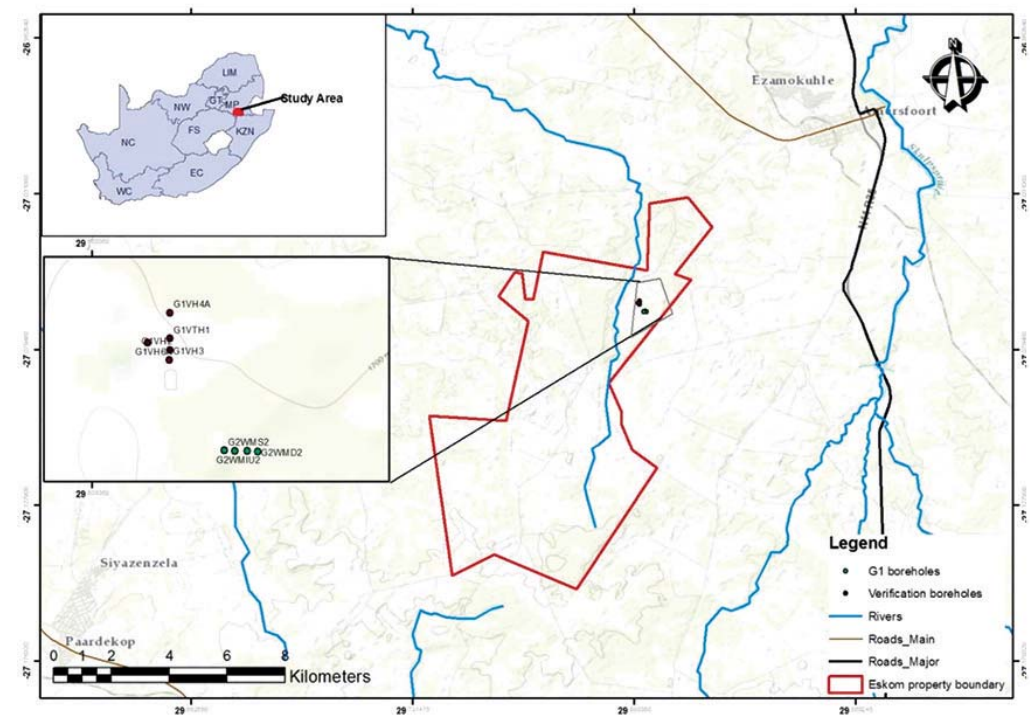

Figure 2-Location map of Majuba UCG pilot plant

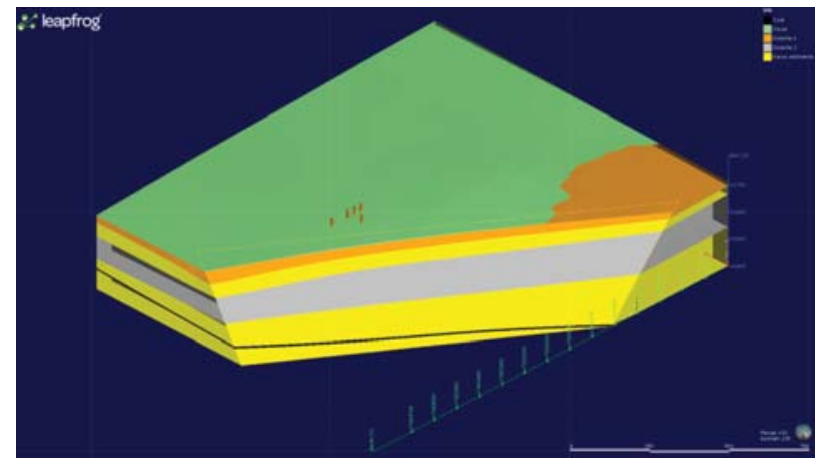

Figure 3-Geological model of the Majuba UCG site

Majuba UCG site it is encountered at a depth of around $280 \mathrm{~m}$ (Pershad, Pistorius, and van der Riet, 2018). The coal zone also bears several thin $(5-20 \mathrm{~cm}$ ) laterally impersistent bright coal layers below the Gus seam (de Oliveira and Cawthorn, 1999). There are three other coal seam above the Gus seam, namely the Eland, Fritz, and Alfred seams. These seams are generally thin and are not targets for gasification.

Interbedded layers of sandstone, shale, and mudstone generally characterize the Karoo sediments (de Oliveira and Cawthorn, 1999).

Three distinct aquifers are present at the Majuba UCG site, as seen in Figure 4. The upper weathered (shallow) aquifer is usually low-yielding (range 1-10 m3/d) owing to its trivial thickness, but contains good quality water due to years of groundwater flow through the weathered strata. The shallow aquifer is estimated to go as deep as $70 \mathrm{~m}$ and is underlain by the intermediate aquifer. Groundwater flow through the intermediate aquifer is mainly through fractures, cracks, and joints induced in the Karoo sediments by the intrusive dolerite sills. The aquifer can be divided into two zones: the intermediate upper (IU) aquifer and intermediate lower (IL) aquifer, as seen in Figure 4.

The coal seam aquifer forms part of the gasification zone and is located at a depth of around $280 \mathrm{~m}$. The confined nature of the coal seam aquifer means the water is under

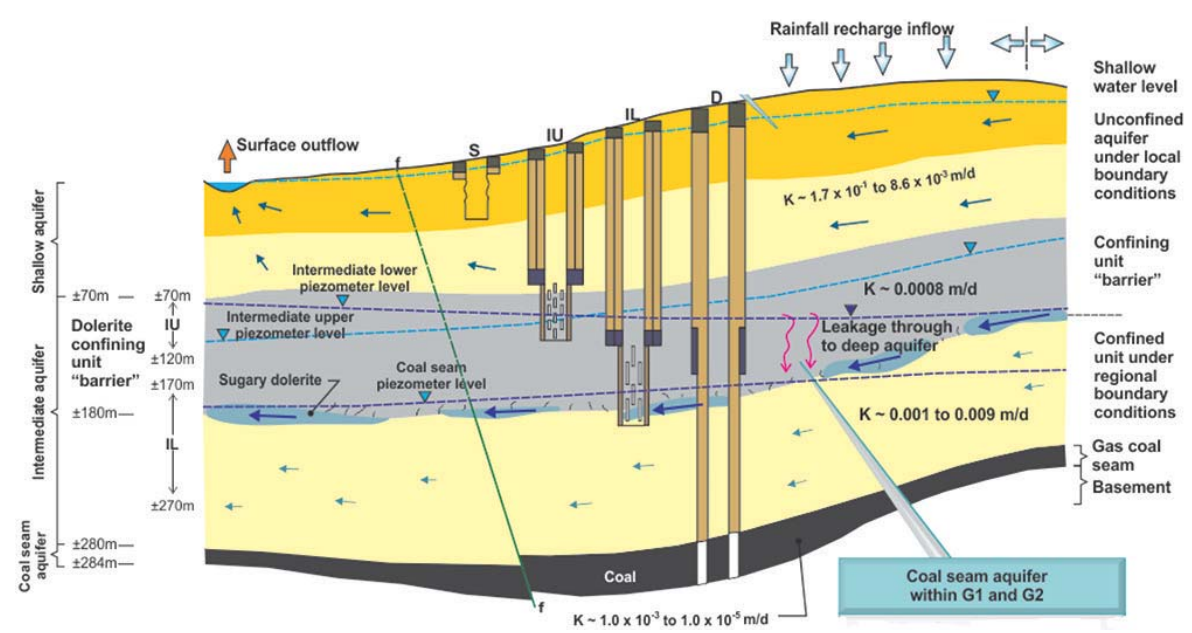




\section{Qualitative hydrogeological assessment of vertical connectivity in aquifers surrounding}

pressure and hence the water level (head) stabilizes at shallow levels around $180 \mathrm{~m}$ below ground. Any fractures in the strata overlying the coal seam can act as a zone of groundwater transmission between the coal seam aquifer and the intermediate aquifer, leading to groundwater mixing. The groundwater in the coal seam aquifer is of poor quality and can generally be classified as saline, while the intermediate aquifer has better quality water. The groundwater monitoring network is placed in such a way that all aquifers are monitored, as depicted by the boreholes in Figure 4 .

\section{Methodology}

Groundwater samples were taken from Majuba UCG site using plastic bailers and analysed for isotope fractions, D/H $\left({ }^{2} \mathrm{H} /{ }^{1} \mathrm{H}\right)$ and ${ }^{18} \mathrm{O} /{ }^{16} \mathrm{O}$, at iThemba Laboratories in Gauteng using a Thermo Delta V mass spectrometer. Equilibration time for the water sample with hydrogen was about 40 minutes and $\mathrm{CO}_{2}$ was equilibrated with a water sample in about 20 hours. Laboratory standards, calibrated against international reference materials, were analysed with each batch of samples. The analytical precision is estimated at $0.2 \%$ for 0 and $0.8 \%$ for $\mathrm{H}$. Analytical results are presented in the common delta-notation:

$$
\delta^{18} O=\left[\left({ }^{18} O /{ }^{16} O_{\text {sample }} /{ }^{18} O /{ }^{16} O v_{\text {-smow }}\right)-1\right] \times 1000
$$

These delta values $\left(\delta^{18} \mathrm{O}\right.$ and $\left.\delta^{2} \mathrm{H}\right)$ are expressed as per mil deviation relative to a known standard, in this case standard mean ocean water (SMOW). The samples were taken from all the aquifers; shallow, intermediate lower, intermediate upper, and the coal seam aquifer.

Hydrochemical data from the UCG site groundwater monitoring was also used to analyse hydraulic connections at the study site. Groundwater is sampled on a monthly basis from all aquifers using bailers and all samples were conserved and transported to the laboratory for chemical analysis. Major and minor elements were determined together with $\mathrm{pH}$ and electrical conductivity. The groundwater monitoring chemical data was plotted on diagnostic plots for geochemical analysis of the groundwater status.

\section{Results and discussion}

\section{Isotopic analysis}

The isotopic data for $\delta^{18} \mathrm{O}$ and $\delta^{2} \mathrm{H}$ is presented in Table I. The $\delta^{18} 0$ values range from $-7.08 \%$ to $4.15 \%$ while the $\delta^{2} \mathrm{H}$ ranges from $-42.2 \%$ to $14.91 \%$. The stable isotope data is plotted on a $\delta^{18} \mathrm{O} / \delta^{2} \mathrm{H}$ diagram (Figure 5 ) with respect to the global meteoric water line (GMWL). The lack of historical rainfall data for $\delta^{18} \mathrm{O}$ and $\delta^{2} \mathrm{H}$ in the study area prompted the addition of the Pretoria meteoric water line (PMWL) from a Pretoria station which is situated approximately $267 \mathrm{~km}$ from the study area. This station collects and record isotopic rainfall data which is kept in the Global Network of Isotopes in Precipitation (GNIP) database managed by the International Atomic Energy Agency (IAEA). The recorded monthly precipitation data resulted in the following relationship isotopic trend: $2 \mathrm{H}=6.5 \delta^{18} \mathrm{O}+6.4 \%$ (Mook, 2000).

The $\delta^{18} \mathrm{O}$ and $\delta^{2} \mathrm{H}$ values trended along the GMWL and are divided into two clusters, suggesting the possibility of two systems of groundwater at the Majuba UCG site. The samples that were enriched in $\delta^{18} \mathrm{O}$ and $\delta^{2} \mathrm{H}$ were from the shallower aquifers (shallow and intermediate upper), confirming that the water was subjected to the influence of evaporation. The samples showing depletion in $\delta^{18} \mathrm{O}$ and $\delta^{2} \mathrm{H}$ are from the deep aquifer, which confirms that they are not affected by evaporation and that recharge may have been by water from high altitudes, where heavy isotopes were removed from rainfall due to altitude/elevation effect. The variability in water isotopic composition between the shallow and the deep aquifer points to dissimilar recharge events, runoff conditions, sampling period salinity, and altitude effect (Ayadi et al., 2018).

The less negative values were obtained from the upper and lower intermediate aquifers as well as the shallow aquifer. These waters may be more enriched in the stable isotopes since they have a shorter residence time in the ground than the deep aquifer waters.

The deep aquifer is represented by average values of -42 and -7.02 for $\delta^{18} \mathrm{O}$ and $\delta^{2} \mathrm{H}$, respectively. These values are significantly different from the mean values observed in the other aquifers. The deep aquifer samples are clustered separately from the other aquifers. The positioning of the deep aquifer samples is consistent with the position of paleowaters that have equilibrated with surrounding rocks, where little or no evaporation transpires. The deep aquifer is expected to receive little local recharge during precipitation events as compared to other aquifers. It is isolated from the rest of the aquifers with no evidence of mixing.

A clear distinction can be seen in the isotopic signatures of the different aquifer systems depicted in Figure 5 . This is particularly portrayed in the deep and the shallow aquifer where the clustered points are closely packed for each system. One sample from the intermediate upper aquifer plots in the position dominated by the samples from the intermediate lower (encircled in Figure 5), which confirms mixing between the two aquifers through the T2 weathered dolerite but no mixing with the deep aquifer. The deep aquifer and the dam samples are the most distinctive and isolated compared to the other samples.

The evaporation line in Figure 5 has a slope of 4.6, which is in line with the global range of 4 to 8 , for example GMWL

Table I

Isotopic data for groundwater in the study area

\begin{tabular}{|l|c|c|}
\hline $\begin{array}{l}\text { Borehole Identification and } \\
\text { aquifer association }\end{array}$ & $\mathbf{d}^{\mathbf{2}} \mathbf{D}(\%)$ & $\mathbf{d}^{\mathbf{1 8}} \mathbf{O}(\%)$ \\
\hline WMD2 Deep aquifer & -42.2 & -7.08 \\
WMD3 Deep aquifer & -40.9 & -6.98 \\
WMD4 Deep aquifer & -42.0 & -7.01 \\
WMIL2 Intermediate lower & -23.5 & -4.52 \\
WMIL3 Intermediate lower & -27.1 & -4.95 \\
WMIL4 Intermediate lower & -29.1 & -4.79 \\
WMIU1 Intermediate upper & -16.3 & -2.55 \\
WMIU2 Intermediate upper & -25.7 & -4.54 \\
WMIU3 Intermediate upper & -5.4 & -0.24 \\
WMIU4 Intermediate upper & -13.6 & -2.06 \\
WMS2 Shallow & -19.1 & -2.93 \\
WMS3 Shallow & -19.7 & -3.34 \\
WMS4 Shallow & -20.5 & -3.63 \\
Dam & 14.9 & 4.15 \\
\hline
\end{tabular}




\section{Qualitative hydrogeological assessment of vertical connectivity in aquifers surrounding}

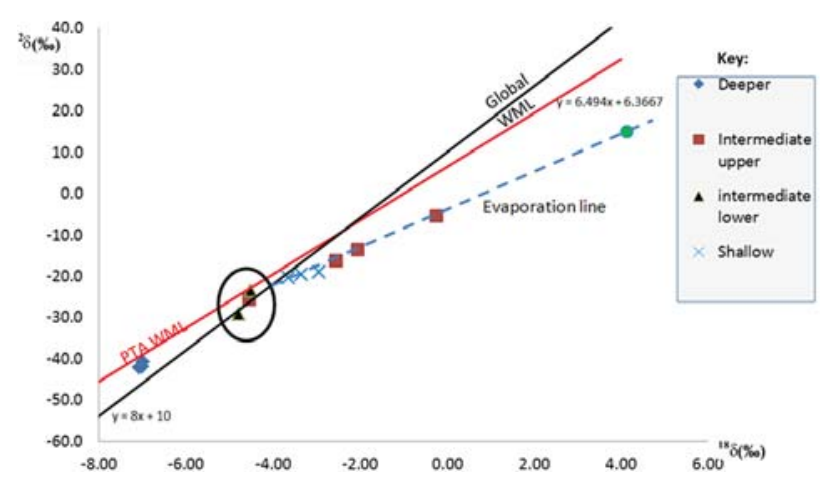

Figure 5-The Craig plot for Majuba UCG site, dam sample is plotted in green

has a slope close to 8 (Clark and Fritz, 1997). The slope depends on the relative humidity, temperature, and concentration in the atmospheric moisture (Yurtsever and Payne, 1978). Relative humidity is fairly constant at $80 \%$ in Mpumalanga Province during the summer season (Govere et al., 2001). The Craig-Gordon (1965) model has established the relationship between the slope of the evaporation line and the relative humidity. The 4.6 slope value relates to a relative humidity value within the $50 \%$ to $75 \%$ range as described by Gordon et al. (1993). This deduced range corresponds with the $80 \%$ relative humidity in the Mpumalanga area. The isotopic signature for the shallow aquifer plots along the evaporation line, which suggests that the water from the surface sampling point (dam) and the shallow aquifer originated from similar precipitation. The shift in the isotopic signature of the dam to more positive $\delta^{18} \mathrm{O}$ and $\delta^{2} \mathrm{H}$ values is due to constant evaporation from the dam favouring the enrichment of water vapour in the lighter isotopes and the heavier isotopes remaining in the dam. The shallow aquifer plots along the evaporation line but with more negative $\delta^{18} 0$ and $\delta^{2} \mathrm{H}$ values compared to the dam. This is due to the isolation of groundwater from the atmosphere upon aquifer recharge, which leads to the isotopic signature being unaffected by fractionation due to evaporation.

The three points from the intermediate upper aquifer also plot along the evaporation line, which suggests that recharge was from the same water source as for the shallow aquifer. The more positive isotopic signature of these three points compared to the shallow aquifer suggest that fractures in the dolerite sill preferentially transmit groundwater, which drains some of the water from the shallow aquifer and transmits it quicker than the sandstones in the shallow aquifer. This means that groundwater that is recharged in the shallow aquifer, with a more positive isotopic signature, will travel slower (longer residence time) through the sandstone matrix. However, if the water encounters fractures at the contact zone of the dolerite sill with the sandstone (where the intermediate upper aquifer is located, see Figure 4) then water flows faster and undergoes less isotopic fractionation due to rock-water interactions. This leads to some of the intermediate upper aquifer points having a more positive isotopic signature than those of the shallow aquifer. This also shows that there is possible mixing between the shallow aquifer and the intermediate upper aquifer.

\section{Hydrochemical analysis}

Monthly groundwater monitoring data over a two-year period was used to characterize the water type of each aquifer system at the Majuba UCG site. The groundwater chemical data was also plotted in an expanded Durov plot as seen in Figure 6. The distinct appearance of the deep aquifer can be seen under the Chloride section, where water with high chloride concentration plots. This is expected, as deep aquifers contain higher levels of sodium chloride salinity due to remnant seawater (Clark and Fritz, 1997). Outliers (red dots) were experienced in only one month; this is likely a sampling or analytical error as this trend did not persist. All the other aquifers plot in the bicarbonate section. While the other aquifers may have similar chemistries it is clear that the deep aquifer maintains its discrete profile. All the samples were taken post-gasification, and from the chemical analyses no link can be established between the deep aquifer and its shallower counterparts. The hydrogeological conceptual model (Figure 4) shows that the three uppermost aquifers may be linked through fractures in the lithology. Fractures and the weathering of the intrusive dolerite rocks can also cause flow to be more rapid in these aquifers compared to the deep coal seam aquifer. This can lead to increased ion exchange in the aquifers which may lead to a sodium bicarbonate water type dominating.

The STIFF diagram in Figure 7 was used to analyse the chemistry of selected average groundwater data from boreholes from each aquifer system. The G2WMD2 (coal seam aquifer) has a distinct chemical profile that is high in $\mathrm{Na}, \mathrm{K}, \mathrm{Cl}$, and $\mathrm{SO}_{4}$. This is typical of deep minewater that has a low flow rate in the aquifer. The other boreholes from the shallower aquifers have high carbonate-bicarbonate levels synonymous with fresh aquifer water.

The general trends from the isotope and chemistry data indicate no link between the deep coal seam aquifer and the shallow aquifer. The deep aquifer is represented by an isotopic signature that is depleted in the heavy isotopes with average values of $-41.7 \%$ and $-7.02 \%$ for $\delta^{18} \mathrm{O}$ and $\delta^{2} \mathrm{H}$ respectively, while the shallow aquifer is enriched with average values of $-19.9 \%$ and $-3.3 \%$. Hydrochemical data also indicated a sodium chloride water type for the deep aquifer and a sodium bicarbonate water for the shallow aquifer.
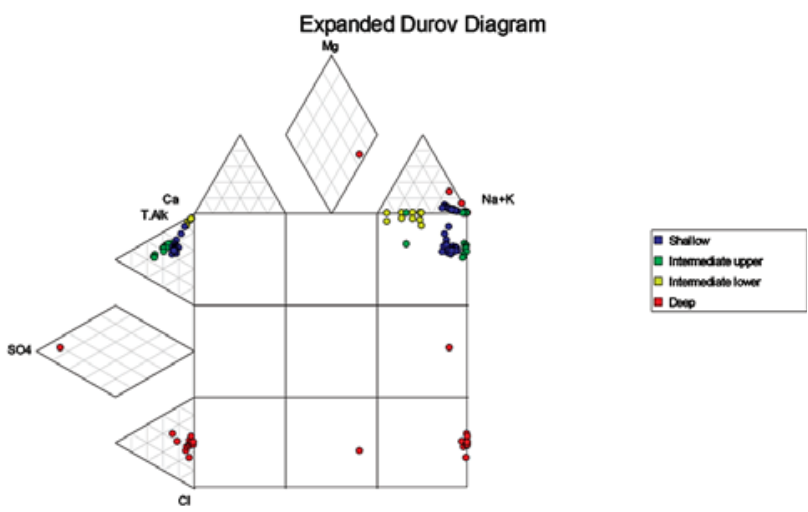

Figure 6-Expanded Durov plot of average groundwater data from different aquifers 


\section{Qualitative hydrogeological assessment of vertical connectivity in aquifers surrounding}

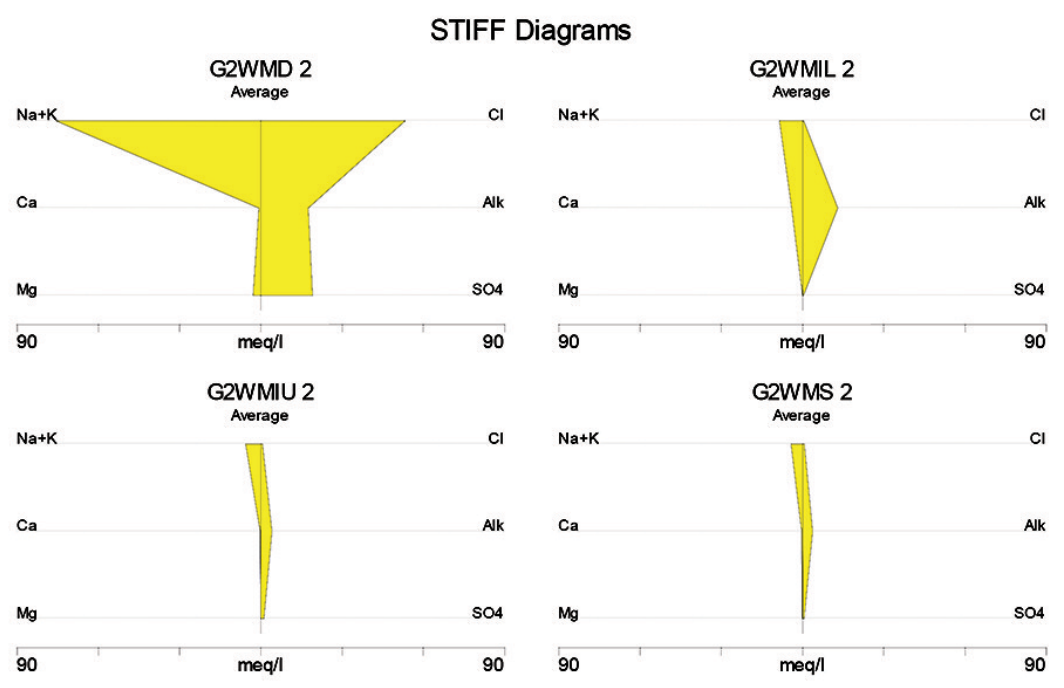

Figure 7-STIFF diagram of selected boreholes

\section{Conclusions}

The conceptual model of the site is supported by the stable isotope and hydrochemistry results. The water from the intermediate upper and intermediate lower aquifers had a mixture of signatures for the stable isotopes. This corresponds to the leakages depicted in the conceptual model that are associated with a weathered dolerite that is found in the intermediate upper and intermediate lower aquifers. The deep aquifer is characterized by an isotopic signature that is depleted in the heavy isotopes, with average values of $41.7 \%$ and $-7.02 \%$ for $\delta^{18} \mathrm{O}$ and $\delta^{2} \mathrm{H}$ respectively, while the shallow aquifer is enriched with corresponding average values of $-19.9 \%$ and $-3.3 \%$. The isotopic signature of the deep aquifer is distinct from those of the shallower aquifers, which confirms that there is no groundwater mixing between these aquifers. Hydrochemical data plotted in the diagnostic plots (expanded Durov and STIFF diagrams) also shows different types of waters: a sodium chloride water type for the deep aquifer and a sodium bicarbonate water for the shallow aquifer. The results show that the shallow aquifer and the deep aquifer are not hydraulically connected and therefore it is unlikely that groundwater from the gasification zone would contaminate the shallow aquifer.

\section{References}

Ayadi, Y., Mokadem, N., Besser, H., Khelifi, F., Harabi, S., Hamad, A., Boyce, A., LAOUAR, R., and HAMED, Y. 2018. Hydrochemistry and stable isotopes $(\delta 180$ and $\delta 2 \mathrm{H})$ tools applied to the study of karst aquifers in southern Mediterranean basin (Teboursouk area, NW Tunisia). Journal of African Earth Sciences, vol. 137. pp. 208-217.

BhutTo, A.W., BAZmi, A.A., and ZAHEDI, G. 2013. Underground coal gasification: From fundamentals to applications. Progress in Energy and Combustion Science, vol. 39, no. 1. pp. 189-214.

Burton, E., Friedmann, J., and Upadhye, R. 2006. Best practices in underground coal gasification. Lawrence Livermore National Laboratory, USA.

CLARK, I. and FRITZ, P. 1997. Environmental Isotopes in Hydrology. Lewis, Boca Raton, FL.

CRAIG, H. and GoRdon, L.I. 1965. Deuterium and oxygen 18 variations in the ocean and the marine atmosphere. Proceedings of Stable Isotopes in Oceanographic Studies and Paleotemperatures, Laboratorio di Geologia Nucleate, Spoleto, Italy. Tongiogi, E. (ed.). V. Lishi e F., Pisa. pp. 9-130. http://climate.colorado.edu/research/CG/
DE OliveirA, D.P.S. and CAWTHoRn, R.G. 1999. Dolerite intrusion morphology at Majuba Colliery, northeast Karoo Basin, Republic of South Africa. International Journal of Coal Geology, vol. 41, no. 4. pp. 333-349.

Dvornikova, E.V. 2018. The role of groundwater as an important component in underground coal gasification. Underground Coal Gasification and Combustion. Blinderman, M.S. and Klimenko, A.Y. (eds.). Woodhead Publishing, Cambridge, UK. pp. 253-281.

Ghasemi, E., Ataei, M., Shahriar, K., Sereshki, F., Jalali, S.E., and RAMAZANZADEH, A. 2012. Assessment of roof fall risk during retreat mining in room and pillar coal mines. International Journal of Rock Mechanics and Mining Sciences, vol. 54. pp. 80-89.

Gordon, J.J., Edward, T.W.D., Bursey, G.G., and Prowse, T.D. 1993. Estimating evaporation using stable isotopes: Quantitative results and sensitivity analysis for two catchments in northern Canada. Nordic Hydrology, vol. 24. pp. 79-94.

Govere, J.M., Durrheima, D.N., CoetzeE, M., and Hunt, R.H. 2001. Malaria in Mpumalanga Province, South Africa, with special reference to the period 1987-1999. South African Journal of Science, vol. 97, no. 1-2. pp. 55-58.

Imran, M., Kumar, D., Kumar, N., QAyyum, A., Saeed, A., and Bhatti, M.S. 2014 Environmental concerns of underground coal gasification. Renewable and Sustainable Energy Reviews, vol. 31. pp. 600-610.

KAPUSTA, K. and STAŃCZYK, K. 2011. Pollution of water during underground coa gasification of hard coal and lignite. Fuel, vol. 90, no. 5. pp. 1927-1934.

KAPUSTA, K. and STAŃczyK, K. 2015. Chemical and toxicological evaluation of underground coal gasification (UCG) effluents. The coal rank effect. Ecotoxicology and Environmental Safety, vol. 112. pp. 105-113.

Liv, S., LI, J., MeI, M., and Dong, D. 2007. Groundwater pollution from underground coal gasification. Journal of China University of Mining and Technology, vol. 17, no. 4. pp. 0467-0472.

Love, D., Beeslar, M.J., Blinderman, M., Pershad, S., van der Linde, G., and van DER RIET, M. 2014. Ground water monitoring and management in underground coal gasification. Proceedings of Unconventional Gas - Just the Facts, Pretoria, South Africa, 18-19 August 2014. Groundwater Division of the Geological Society of South Africa and Mine Water Division of the Water Institute of South Africa.

Моoк, W.G. 2000. Environmental Isotopes in the Hydrological Cycle, Volume 1: Introduction. IHP-V, UNESCO, Paris. 280 pp. http://www.iaea.org.at/programmes/ripc/ih/volumes/volumes.htm [accessed 28 August 2018].

Pershad, S., Pistorius, J., and van Der Riet, M. 2018. Majuba underground coal gasification project. Underground Coal Gasification and Combustion. Blinderman, M.S. and Klimenko, A.Y. (eds.). Woodhead Publishing, Cambridge, UK. pp. 469-502.

Wilson, M.G.C. and Anhaeusser, C.R. (eds.). 1998. The Mineral Resources of South Africa. Handbook no. 16. Council for Geoscience, Pretoria.

Yurtsever, Y. and Payne, B.R. 1978. Application of environmental isotopes to groundwater investigation in Qatar. Proceeding of the International Symposium on Isotope Hydrology, Neuherberg, Germany, 19-23 June 1978, vol. 2. International Atomic Energy Agency, Vienna. pp. 465-490. 